\title{
Antidiabetic Activity of Caulerpa racemosa: Role of Proinflammatory Mediators, Oxidative Stress, and Other Biomarkers
}

(ㅇ)(요 $\odot$

Authors

Rahul V. Mandlik ${ }^{1,2}$, Suresh R. Naik ${ }^{3}$, Sandip Zine ${ }^{4}$, Hemen Ved ${ }^{5}$, Gaurav Doshi ${ }^{5}$

\section{Affiliations}

1 Faculty of Pharmacy, Pacific Academy of Higher Education and Research, Pacific Hills, Udaipur, India

2 Medical Affairs, Shalina Healthcare DMCC, Almas Tower, Dubai, UAE

3 Ex-Dean, Sinhgad Institute of Pharmaceutical Sciences, Kusgaon (Bk), Lonavala, India

4 Department of Pharmaceutical Chemistry, SVKM's Dr Bhanuben Nanavati College of Pharmacy, Vile Parle, Mumbai, India

5 Department of Pharmacology, SVKM's Dr Bhanuben Nanavati College of Pharmacy, Vile Parle, Mumbai, India

Key words

seaweed, Caulerpa racemosa, Caulerpaceae, type 2 diabetes mellitus, antioxidant, anti-inflammatory

received 23.08 .2021

revised 14.10 .2021

accepted 29.11.2021

\section{Bibliography}

Planta Med Int Open 2022; 9: e60-e71

DOI 10.1055/a-1712-8178

ISSN 2509-9264

(C) 2022. The Author(s).

This is an open access article published by Thieme under the terms of the Creative Commons Attribution-NonDerivative-NonCommercial-License, permitting copying and reproduction so long as the original work is given appropriate credit. Contents may not be used for commecial purposes, or adapted, remixed, transformed or built upon. (https://creativecommons. org/licenses/by-nc-nd/4.0/)

Georg Thieme Verlag KG, Rüdigerstraße 14,

70469 Stuttgart, Germany

Correspondence

Rahul V. Mandlik

Faculty of Pharmacy

Pacific Academy of Higher Education and Research

Pacific Hills

Pratap Nagar Extension

Airport Road, Udaipur

313001 Rajasthan

India

rahulmandlik30@gmail.com

\section{ABSTRACT}

A marine alga, Caulerpa racemose (seaweed), exhibits few biological activities, such as antinociceptive/anti-inflammatory, antitumor, and growth regulator. This study aimed to determine the antidiabetic activity of this seaweed. High-performance thin-layer chromatography of $C$. racemosa ethanolic extract was performed to identify its active constituents. Antidiabetic activity of $C$. racemosa ethanolic extract (100 and $200 \mathrm{mg} / \mathrm{kg}$ ) was evaluated using various biochemical paradigms against glipizide $(5 \mathrm{mg} / \mathrm{kg}$ ) in a streptozotocin-induced diabetes rat model. High-performance thin-layer chromatography revealed $\beta$-sitosterol as an active constituent and also indicated the presence of saponins and alkaloids. Treatment with $C$. racemosa ethanolic extract significantly reduced blood glucose levels in diabetic rats, and the degree of glucose reduction was comparable to that attained by glipizide treatment. The $C$. racemosa ethanolic extract treatment restored the impaired glycosylated hemoglobin level, liver glycogen level, glucose uptake by hemidiaphragm, and glucose transport by hepatic cells. Pretreatment with C. racemosa ethanolic extract also restored lipid abnormalities, elevated liver enzymes, elevated inflammatory markers, and depleted endogenous antioxidants. A superior effect was shown by $C$. racemosa ethanolic extract $(200 \mathrm{mg} / \mathrm{kg}$ ) over glipizide $(5 \mathrm{mg} / \mathrm{kg})$. Moreover, the restoration of the histoarchitecture of the pancreas by $C$. racemosa ethanolic extract $(200 \mathrm{mg} / \mathrm{kg})$ was comparable to that of the glipizide $(5 \mathrm{mg} / \mathrm{kg})$ treatment group. The present experimental findings demonstrate significant antidiabetic activity of $C$. racemosa ethanolic extract in diabetic rats using various biochemical paradigms. Further, $C$. racemosa ethanolic extract seems to be safe and does not affect vital organs adversely. 


$\begin{array}{ll}\text { ABBREVIATIONS } \\ \text { ALP } & \text { Alkaline phosphatase } \\ \text { ALT } & \text { Alanine transaminase } \\ \text { AST } & \text { Aspartate Aminotransferase } \\ \text { CaR } & \text { Caulerpa racemosa } \\ \text { CaRE } & \text { Caulerpa racemosa ethanolic extract } \\ \text { CAT } & \text { catalase } \\ \text { CMC } & \text { carboxymethylcellulose } \\ \text { GSH } & \text { glutathione } \\ \text { HDL } & \text { high-density lipoproteins } \\ \text { HPTLC } & \text { high-performance thin-layer chromatography } \\ \text { IL-4 } & \text { interleukin -4 } \\ \text { LDL } & \text { low-density lipoprotein } \\ \text { MDA } & \text { malondialdehyde } \\ \text { NEFA } & \text { non-esterified fatty acids } \\ \text { SGOT } & \text { serum glutamate oxaloacetate transaminase } \\ \text { SGPT } & \text { serum glutamate pyruvate transaminase } \\ \text { STZ } & \text { streptozotocin } \\ \text { SOD } & \text { superoxide dismutase } \\ \text { TC } & \text { total cholesterol } \\ \text { TGA } & \text { triglyceride } \\ \text { VLDL } & \text { very-low-density lipoprotein } \\ & \end{array}$

\section{Introduction}

Natural compounds derived from plant, microbial, and marine sources have been extensively used for therapeutic purposes since time immortal. However, their extensive use and increasing demand have resulted in insufficient plant-derived materials to satisfy market demands. Further, phytochemical research has focused more attention on discovering novel beneficial natural products. This situation has immensely contributed to stimulating the increasing interest in unconventional and unexplored sources of natural products. In this context, marine algae have attracted much attention over the past four decades [1]. Algae are omnipresent globally and are an important part of the aquatic ecosystem. Several seaweed species are used as therapeutics as well as food. The rheological properties of seaweeds have made them crucial as food additives. Apart from that, several bioactive compounds from marine algae are also known to exhibit various biological activities [2]. However, it has been observed from the literature that seaweeds are not investigated extensively for their antidiabetic activity.

Despite the presence of several hypoglycemic agents in the market, type 2 diabetes mellitus remains a major global health problem. Herbal products may act by several mechanisms to alleviate the diabetic symptoms, deriving multifaceted benefits [3]. Of all the herbal alternatives, the therapeutic properties of marine algae are the least explored. The hypoglycemic potential and bioactive compound present in seaweeds is a new unexplored potential area $[4,5]$.

These marine compounds either exhibit direct hypoglycemic activity or ameliorate complications associated with type 2 diabetes mellitus through other properties, viz. antioxidant, anti-inflammatory membrane stabilization, etc. Several animal studies have indicated an association between oxidative inflammation and the incidence of type 2 diabetes mellitus. Previous studies have shown that hyperglycemia and insulin resistance in diabetic patients lead to an elevated generation of reactive oxygen species [6, 7]. Furthermore, metabolic syndrome and insulin resistance are also associated with the generation of acute-phase inflammatory markers, showing the key role played by chronic low-grade inflammation in type 2 diabetes mellitus progression.

Seaweeds have traditionally been considered active agents for the treatment of inflammation, cancer, type 2 diabetes mellitus, bacterial infections, and obesity. CaR (sea grapes) is green seaweed that belongs to the Caulerpaceae family. CaR is extensively spread in tropical areas, particularly in Indo-Pacific Asia, where it is eaten either raw as a salad or cooked in vegetable soups. CaR has been considered a rich source of various bioactive components. Chemical analysis of $\mathrm{CaR}$ conducted previously has shown that $\mathrm{CaR}$ is rich in chemical constituents such as proteins, lipids, minerals, pigments, and vitamins [8]. Polysaccharides or polysaccharide extracts from CaR exhibit significant anticancer, anti-inflammatory, antibacterial, antiobesity, and antidiabetic properties [9]. Previous studies have also shown that CaR exhibits potent antioxidant activity [9]. Various extracts of CaR have also shown potent larvicidal activity [10]. No toxicity was seen in the sulfated polysaccharides detected in CaR and these reduced nociception and inflammatory activities are partly attributed to the activation of the hemoxigenase-1 pathway [11]. These data suggest that CaR not only exhibits versatile medicinal properties but it also is safe. Moreover, active components of CaR have the potential to activate various signaling pathways, such as immune signaling pathways, which can modulate the immune response for treatment of various diseases and disorders. With this background information, CaR was selected for this study. Phytochemical and acute toxicity studies were performed. Since the extracts were found to be safe, they were studied for hypoglycemic activity. Subsequently, its antidiabetic activity was evaluated in an STZ-induced diabetic rat model, along with its impact on proinflammatory markers, antioxidants, lipid, and serum biomarkers, and histoarchitecture of the pancreas to understand its underlying mechanisms of hypoglycemic activity $[12,13]$.

\section{Results}

The fingerprinting pattern of CaRE was studied using HPTLC. Around 15 different peaks were noted on the HPTLC fingerprint of CaRE ( $\triangleright$ Figs. 1 and $\triangleright 2$ ). The plate was derivatized with Liebermann-Burchard reagent showed a pink colored compound, which was identified as $\beta$-sitosterol, ( $\triangleright$ Fig. 3 ) and others that saponins (like oleanolic acid, ursolic acid, and lupeol) as active constituents. Other plates sprayed with Dragendorff reagent showed only one compound, which presumably belonged to the alkaloid group.

In acute toxicity, the administration of CaRE at various doses did not lead to mortality until concentrations up to $2000 \mathrm{mg} / \mathrm{kg}$ body weight. Even at this dose, there were no gross behavioral changes or any adverse clinical symptoms, except mild sedation and analgesia. The rats were monitored once during first 30 min post-dosing and subsequently up to $24 \mathrm{~h}$, followed by daily observation for 14 days. 
Track 3 . ID: SAMPLE

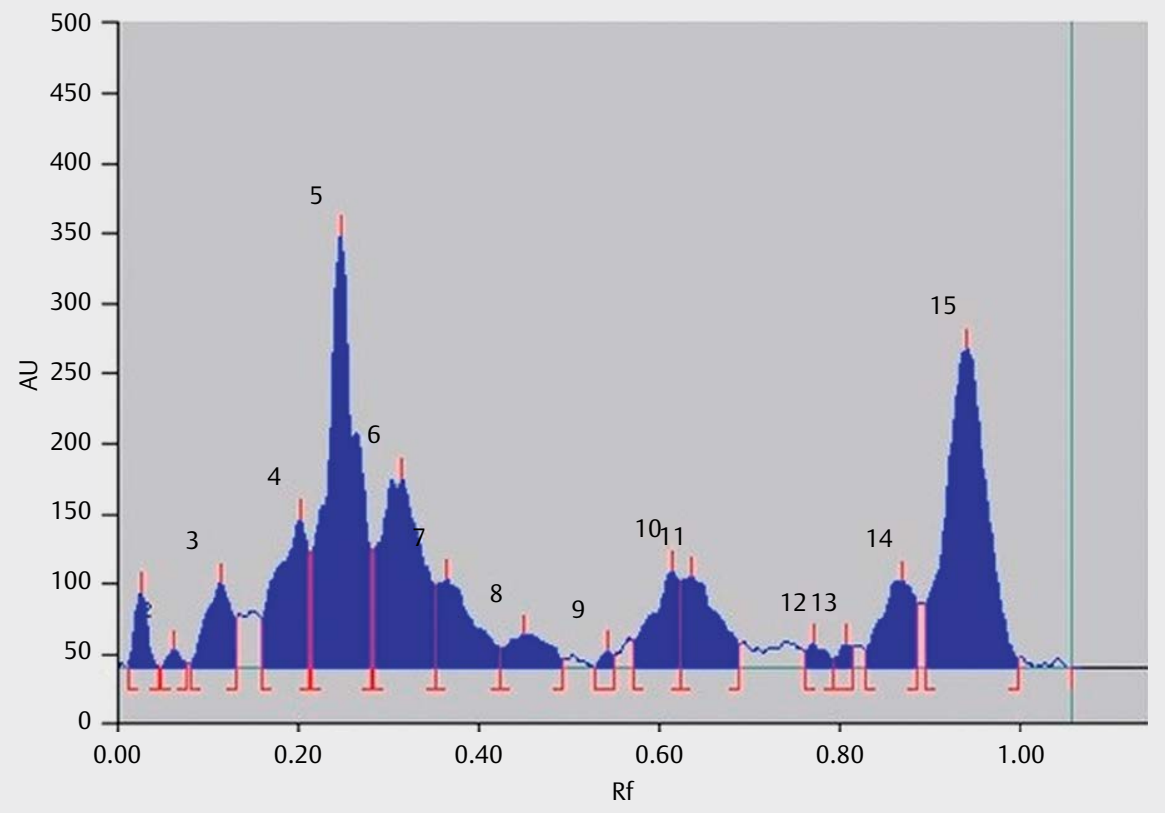

- Fig. 1 HPTLC fingerprint of CaRE; solvent system petroleum ether: acetone (8:2 v/v) (Peak 6: Rf 0.38, peak area 5984.2).

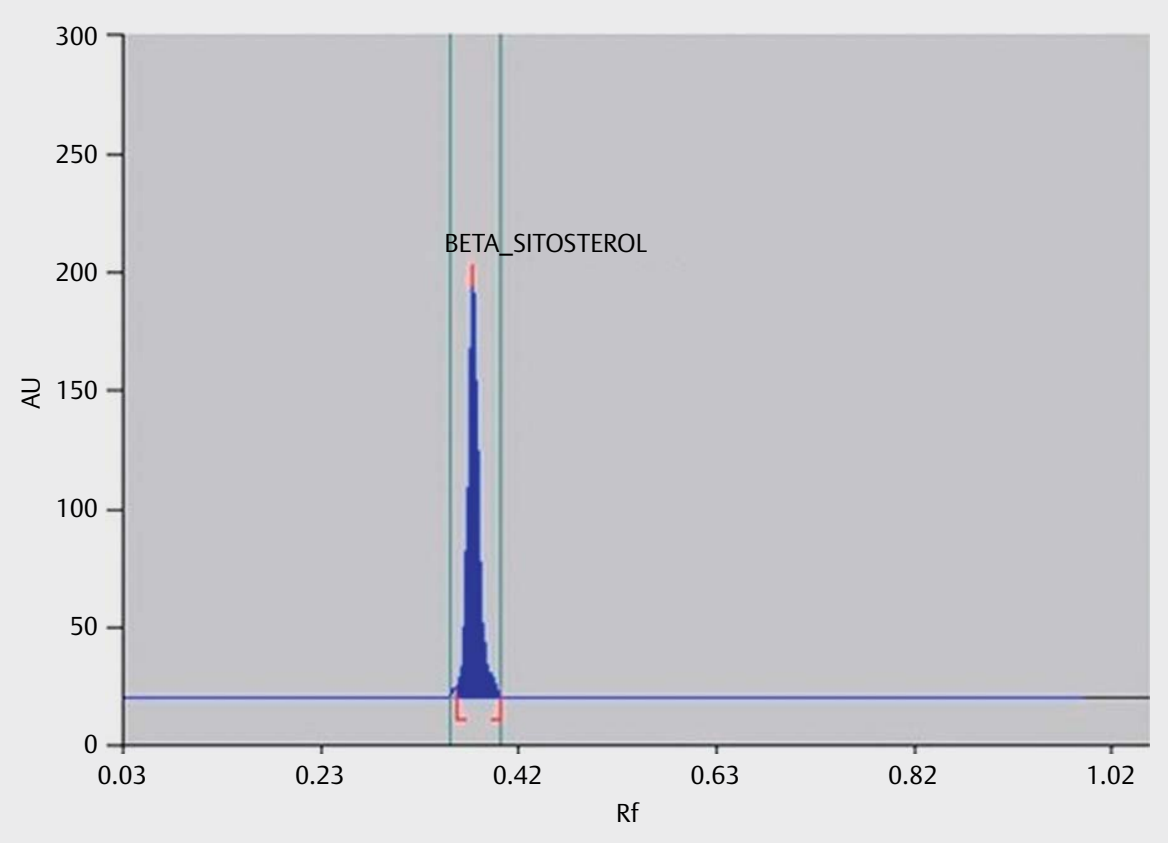

Fig. 2 Peak display of standard ß-sitosterol in CaRE.

A single-dose administration of the CaRE $(200 \mathrm{mg} / \mathrm{kg})$ on the 4th day after STZ administration led to a significant reduction in blood glucose levels at 1 and $6 \mathrm{~h}(\mathrm{p}<0.01)$. However, at $100 \mathrm{~m} / \mathrm{kg}$ dose, CaRE did not elicit any significant blood glucose reduction. Glipizide $(5 \mathrm{mg} / \mathrm{kg}$ ) treatment led to a greater reduction in blood glucose levels at $6 \mathrm{~h}$ compared to CaRE treatment ( $\triangleright$ Table $\mathbf{1}$ ).
STZ-induced diabetic rats showed a significant elevation in the levels of blood glucose. Oral administration of CaRE (100 and $200 \mathrm{mg} / \mathrm{kg} /$ day) and glipizide ( $5 \mathrm{mg} / \mathrm{kg} /$ day) to STZ-treated diabetic rats significantly reduced the levels of blood glucose. In groups treated with $200 \mathrm{mg} / \mathrm{kg}$ CaRE and $5 \mathrm{mg} / \mathrm{kg}$ glipizide, glucose levels reduced to almost normal levels. Treatment with both doses of 


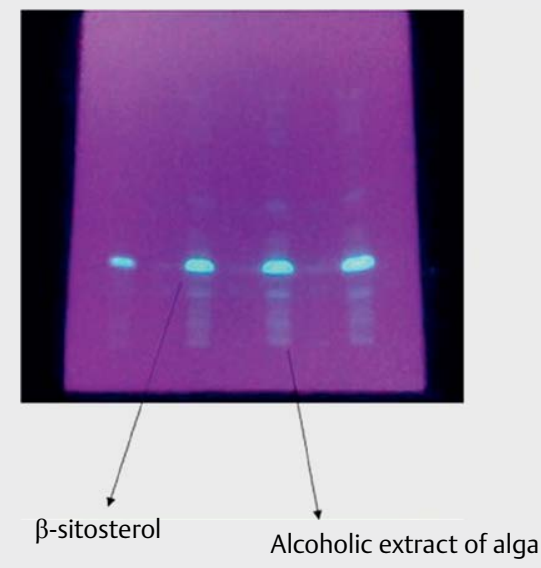

Before derivatization at $366 \mathrm{~nm}$

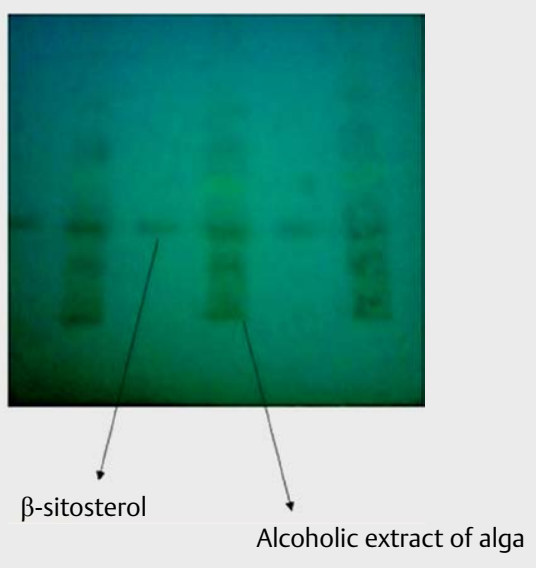

After derivatization

Fig. 3 HPTLC pattern of CaRE before and after derivatization at $366 \mathrm{~nm}$.

- Table 1 Acute and Sub-acute effects of CaRE on STZ-diabetic rats.

\begin{tabular}{|c|c|c|c|c|}
\hline \multicolumn{5}{|c|}{ Acute effect of CaRE on STZ-diabetic rats } \\
\hline \multirow[t]{2}{*}{$\begin{array}{l}\text { Group and Treatment } \\
(\mathrm{mg} / \mathrm{kg}, \mathrm{p.o})\end{array}$} & \multicolumn{2}{|l|}{$\begin{array}{l}\text { Blood glucose }(\mathrm{mg} \%) \text { at different } \\
\text { time intervals (Mean } \pm \text { SEM, } \\
n=6 \text { ) }\end{array}$} & & \\
\hline & $\mathbf{O} \mathbf{h}$ & $1 \mathrm{~h}$ & $3 \mathbf{h}$ & $6 \mathrm{~h}$ \\
\hline Normal control & $62.30 \pm 6.30$ & $62.83 \pm 5.90$ & $63.02 \pm 7.10$ & $63.11 \pm 6.90$ \\
\hline Diabetic control & $492.33 \pm 52.30$ & $499.40 \pm 57.60^{\# \#}$ & $433.50 \pm 29.60^{\# \#}$ & $422.60 \pm 44.10^{\# \#}$ \\
\hline CaRE (100) & $445.20 \pm 49.30$ & $433.33 \pm 47.80^{\mathrm{NS}}$ & $424.30 \pm 42.30 \mathrm{NS}$ & $438.30 \pm 54.30$ NS \\
\hline CaRE (200) & $467.30 \pm 49.60$ & $366.16 \pm 38.60 * *$ & $420.30 \pm 52.80^{*}$ & $132.20 \pm 22.10^{* *}$ \\
\hline Glipizide (5) & $467.00 \pm 46.00$ & $272.50 \pm 21.30^{*}$ & $268.82 \pm 28.60^{* *}$ & $69.00 \pm 8.90^{* *}$ \\
\hline \multicolumn{5}{|c|}{$\begin{array}{l}\text { Sub-acute effect of CaRE } \\
\text { on STZ-diabetic rats }\end{array}$} \\
\hline \multirow[t]{2}{*}{$\begin{array}{l}\text { Group and Treatment } \\
(\mathrm{mg} / \mathrm{kg}, \mathrm{p.o})\end{array}$} & $\begin{array}{l}\text { Blood glucose (mg } \%) \text { at various } \\
\text { time intervals (days) } \\
\text { (Mean } \pm \text { SEM, } n=6 \text { ) }\end{array}$ & & & \\
\hline & 10 & 20 & 30 & \\
\hline Normal control & $63.66 \pm 2.90$ & $62.16 \pm 2.40$ & $63.33 \pm 2.40$ & \\
\hline Diabetic control & $389.66 \pm 3.80^{\# \#}$ & $531.83 \pm 3.30^{\# \#}$ & $449.16 \pm 4.50^{\# \#}$ & \\
\hline CaRE (100) & $355.50 \pm 4.90 * *$ & $261.40 \pm 3.50^{* *}$ & $108.66 \pm 4.60^{* *}$ & \\
\hline CaRE (200) & $115.16 \pm 5.05^{* *}$ & $90.83 \pm 3.50 * *$ & $94.33 \pm 1.70^{* *}$ & \\
\hline Glipizide ( 5) & $80.33 \pm 3.50^{* *}$ & $125.63 \pm 6.00^{* *}$ & $91.16 \pm 3.60^{* *}$ & \\
\hline
\end{tabular}

CaRE led to a significant reduction in levels of blood glucose and its hypoglycemic effect was comparable to that of $5 \mathrm{mg} / \mathrm{kg}$ glipizide on the 30th day ( $\triangleright$ Table $\mathbf{1}$ ).

In STZ diabetic rats, glucose uptake by the hemidiaphragm was markedly reduced. Administration of CaRE $(100$ and $200 \mathrm{mg} / \mathrm{kg} /$ day) significantly improved the glucose uptake via the hemidiaphragm $(p<0.01)$ ( not exhibit increased glucose uptake via the hemidiaphragm. STZ treatment led to a significant reduction in hepatic levels of glycogen ( $\triangleright$ Table 2). Pretreatment with CaRE (200 mg/kg/day) signifi- cantly prevented depletion of hepatic glycogen in STZ diabetic rats. The administration of glipizide ( $5 \mathrm{mg} / \mathrm{kg} /$ day) also significantly alleviated the liver glycogen reduction $(p<0.01)$ in STZ diabetic rats.

STZ-induced diabetic rats also exhibited a marked increase in the levels of HbA1c. Treatment with CaRE significantly reduced, dose-dependently, the elevated HbA1c levels ( $>$ Table 2 ). A similar reduction in the blood glucose level was also observed after glipizide $(5 \mathrm{mg} / \mathrm{kg})$ treatment. Treatment with both CaRE and glipizide produced significantly $(p<0.01)$ inhibited glucose transport in liver slices of STZ diabetic rats ( $\triangleright$ Table 2 ). STZ diabetic rats exhibited 
- Table 2 Effect of CaRE on various carbohydrate metabolism and lipid profile parameters in STZ-diabetic rats.

\begin{tabular}{|c|c|c|c|c|c|}
\hline \multicolumn{6}{|c|}{ Effect of CaRE on various carbohydrate metabolism parameters in STZ-diabetic rats } \\
\hline \multirow[t]{2}{*}{$\begin{array}{l}\text { Group and Treatment } \\
(\mathrm{mg} / \mathrm{kg}, \mathrm{p.o})\end{array}$} & $\begin{array}{l}\text { Glycosylated } \\
\text { haemoglobin } \\
\text { (Hb1Ac\%) }\end{array}$ & $\begin{array}{l}\text { Glucose uptake by } \\
\text { diaphragm (mg/100 mg) }\end{array}$ & $\begin{array}{l}\text { Liver glycogen } \\
\text { (mg/gm) }\end{array}$ & $\begin{array}{l}\text { Glucose transfer by } \\
\text { liver ( } \mathrm{mg} / \mathrm{gm} \text { ) }\end{array}$ & \\
\hline & $($ Mean $\pm S E M, n=6)$ & & & & \\
\hline Normal control & $5.00 \pm 0.50$ & $18.00 \pm 2.10$ & $41.00 \pm 5.00$ & $19.66 \pm 1.10$ & \\
\hline Diabetic control & $12.00 \pm 1.30^{\# \#}$ & $4.00 \pm 0.60^{\# \#}$ & $13.00 \pm 1.80^{\# \#}$ & $35.66 \pm 3.80^{\# \#}$ & \\
\hline CaRE (100) & $7.00 \pm 0.70^{* *}$ & $9.20 \pm 1.10^{*}$ & $18.00 \pm 2.30$ & $12.35 \pm 1.90^{* *}$ & \\
\hline CaRE (200) & $6.00 \pm 0.80^{* *}$ & $12.60 \pm 1.80^{* *}$ & $28.00 \pm 3.40^{* *}$ & $13.16 \pm 1.05^{* *}$ & \\
\hline Glipizide (5) & $8.00 \pm 0.90^{*}$ & $6.00 \pm 0.50$ & $34.00 \pm 4.60 * *$ & $17.33 \pm 1.50 * *$ & \\
\hline \multicolumn{6}{|c|}{ Effect of CaRE on lipid profile in STZ-diabetic rats } \\
\hline $\begin{array}{l}\text { Group and Treatment } \\
(\mathrm{mg} / \mathrm{kg}, \text { p.o.) }\end{array}$ & $\begin{array}{l}\text { Total cholesterol } \\
\text { (mg/dL) }\end{array}$ & Triglycerides (mg/dL) & VLDL (mg/dL) & LDL (mg/dL) & $\begin{array}{l}\text { HDL cholesterol } \\
(\mathrm{mg} / \mathrm{dL})\end{array}$ \\
\hline Normal control & $71.20 \pm 5.29$ & $98.60 \pm 10.03$ & $12.20 \pm 2.03$ & $37.32 \pm 3.13$ & $58.26 \pm 61.91$ \\
\hline Diabetic control & $146.40 \pm 10.10^{\# \#}$ & $212.60 \pm 23.51^{\# \#}$ & $44.70 \pm 6.88^{\# \#}$ & $177.70 \pm 22.51^{\# \#}$ & $21.30 \pm 1.17^{\# \#}$ \\
\hline CaRE (100) & $92.00 \pm 9.45^{* *}$ & $178.70 \pm 23.63^{* *}$ & $28.52 \pm 3.83^{* *}$ & $97.99 \pm 10.13^{* *}$ & $39.80 \pm 6.70^{* *}$ \\
\hline CaRE (200) & $88.40 \pm 9.58^{* *}$ & $146.60 \pm 22.67^{* *}$ & $19.96 \pm 2.89^{* *}$ & $82.24 \pm 8.57^{* *}$ & $45.90 \pm 4.17^{* *}$ \\
\hline Glipizide (5) & $101.80 \pm 12.50^{*}$ & $189.80 \pm 14.05^{*}$ & $31.06 \pm 4.85^{*}$ & $130.36 \pm 14.16^{*}$ & $32.60 \pm 5.68^{*}$ \\
\hline
\end{tabular}

significantly elevated levels of TGA, TC, VLDL, and LDL, and a decrease in the level of HDL in the serum $(p<0.01)$. Treatment with CaRE (100 and $200 \mathrm{mg} / \mathrm{kg} /$ day) significantly ameliorated the effects of STZ ( $\triangleright$ Table 2). Administration of glipizide also produced a similar effect on serum lipid levels.

The degree of lipid peroxidation was evaluated in terms of MDA formation. Increased MDA levels were observed in the liver andpancreas of STZ diabetic rats ( $\triangleright$ Table 3 ). In addition, a concomitant depletion of endogenous antioxidants enzymes, viz. CAT, GSH, and SOD, was observed in the liver and pancreas of STZ diabetic rats. Pretreatment with CaRE (100 and $200 \mathrm{mg} / \mathrm{kg} /$ day) significantly prevented MDA formation and restored the depleted levels of GSH, CAT, and SOD in the liver and pancreas of STZ diabetic rats ( $\triangleright$ Table 3). Treatment with $200 \mathrm{mg} / \mathrm{kg}$ CaRE led to a greater restoration of depleted antioxidants compared to treatment with glipizide in STZ diabetic rats.

STZ diabetic mice exhibited significantly elevated TNF- $\alpha$ and IL-4 levels in serum. Treatment with CaRE prevented the elevation of TNF- $\alpha$ and IL-4 levels in serum. The inhibitory effect of CaRE $(200 \mathrm{mg} / \mathrm{kg} /$ day) on serum TNF- $\alpha$ and IL-4 levels was greater than that observed after glipizide $(5 \mathrm{mg} / \mathrm{kg} /$ day) treatment ( $\triangleright$ Table 4$)$.

STZ diabetic mice exhibited significantly elevated levels of serum liver biomarkers (AST, ALT, and ALP). Treatment with CaRE (100 and $200 \mathrm{mg} / \mathrm{kg} /$ day) for 30 days significantly prevented the elevation of these biomarkers. Glipizide $(5 \mathrm{mg} / \mathrm{kg} /$ day) treatment also reduced the levels of serum biomarkers significantly; however, the degree of reduction was less compared to that obtained after CaRE treatment ( $\vee$ Table 4 ). The depleted serum levels of albumin and total protein were also restored significantly after treatment with CaRE and glipizide ( $\triangleright$ Table 4).

Control groups exhibited no abnormalities in the histoarchitecture of the pancreas ( $\triangleright$ Fig. 4a). However, STZ diabetic rats exhibited moderate to severe necrotic alterations in $\beta$-islets of Langerhans ( $\triangleright$ Fig. 4b). In a few mice, only a sporadic presence could be observed. CaRE-treated ( $200 \mathrm{mg} / \mathrm{kg} /$ day) mice exhibited mild to moderate necrosis in $\beta$-islets ( $\triangleright$ Fig. $4 \mathbf{d d}$ ), which was comparable to that observed in glipizide-treated $(5 \mathrm{mg} / \mathrm{kg} /$ day) groups ( $\mathbf{F i g . 4 e}$ ). Furthermore, CaRE $(100 \mathrm{mg} / \mathrm{kg} /$ day) treatment led to mild improvement in the necrosis of $\beta$-islets ( $\vee \mathbf{F i g} .4 \mathbf{c}$ ); however, the reduction in the number and size of $\beta$-islets was not significantly improved.

\section{Discussion}

Alcoholic extracts of marine algae CaRE were studied for fingerprinting patterns using HPTLC. We used several solvent systems, of which petether:acetone $(8: 2 \mathrm{v} / \mathrm{v})$ was found to be most suitable for optimum resolution. Around 15 different peaks were detected and showed $\mathrm{Rf}$ at $0.05,0.07,0.12,0.20,0.38,0.40,0.44,0.53$, $0.60,0.63,0.78,0.80,0.89$, and 0.99 , which is represented in \% area as 450.3,256.1,956.3,1665.9, 7865.1, 5984.2, 4589.3, 658.1, $125.0,357.3,542.0,170.3,100.3,564.2$, and 9842.2 respectively ( $>$ Figs. 1-3). The plate was derivatized with Liberman-Burchared reagent, revealing a pink colored compound that comprised sitosterol and saponins as active constituents. When a plate was sprayed using Dragandorff reagent, only one compound, probably an alkaloid, was identified.

In this study, we observed that CaRE elicited marked hypoglycemic activity compared to other extracts and was also found to have a safe toxicity profile. STZ is a selective pancreatic islets $\beta$ cell cytotoxic agent and hence widely used to induce type 2 diabetes mellitus in rodents [14]. Intraperitoneal administration of STZ $(55 \mathrm{mg} / \mathrm{kg}$ ) to rats simulates conditions similar to type 2 diabetes mellitus, such as the elevation of blood glucose, glycosylated hemoglobin, and liver glycogen levels, along with a significant decrease in glucose uptake by the hemidiaphragm, increased glucose secretion by hepatic cells, and gluconeogenesis (deceased glucose transport for the formation of amino acids, citrate, etc.) [15]. Treat- 
- Table 3 Effects of CaRE on liver MDA and pancreatic MDA antioxidant enzymes in STZ-diabetic rats.

\begin{tabular}{|c|c|c|c|c|}
\hline \multicolumn{5}{|c|}{ Effects of CaRE on liver MDA and antioxidant enzymes in STZ-diabetic rats } \\
\hline \multirow[t]{2}{*}{ Group and Treatment (mg/kg, p.o.) } & $\begin{array}{l}\text { Antioxidants enzymes } \\
\text { (Mean } \pm \text { SEM, } n=6 \text { ) }\end{array}$ & & & \\
\hline & MDA (nM of MDA/gm) & GSH (mg GSH/gm) & CAT $\left(\mu \mathrm{M}\right.$ of $\left.\mathrm{H}_{2} \mathrm{O}_{2} / \mathrm{gm}\right)$ & SOD (U/mg) \\
\hline Normal control & $7.20 \pm 0.80$ & $1.60 \pm 0.30$ & $36.32 \pm 3.10$ & $66.10 \pm 8.20$ \\
\hline Diabetic control & $14.60 \pm 2.40^{\# \#}$ & $1.10 \pm 0.20^{\#}$ & $17.30 \pm 1.30^{\#}$ & $35.00 \pm 2.30^{\#}$ \\
\hline CaRE (100) & $10.10 \pm 1.20^{*}$ & $1.40 \pm 0.20 *$ & $26.90 \pm 1.30^{*}$ & $46.80 \pm 2.30^{*}$ \\
\hline CaRE (200) & $8.83 \pm 1.00^{* *}$ & $1.50 \pm 0.30^{* *}$ & $32.87 \pm 4.70^{* *}$ & $56.50 \pm 6.30^{* *}$ \\
\hline Glipizide (5) & $11.20 \pm 1.40$ & $1.20 \pm 0.20$ & $24.30 \pm 3.50$ & $44.90 \pm 6.80^{*}$ \\
\hline \multicolumn{5}{|c|}{ Effects of CaRE on pancreatic MDA and antioxidant enzymes in STZ-diabetic rats } \\
\hline \multirow[t]{2}{*}{ Group and Treatment (mg/kg, p.o.) } & $\begin{array}{l}\text { Antioxidants enzymes } \\
\text { (Mean } \pm \text { SEM, } n=6 \text { ) }\end{array}$ & & & \\
\hline & $\begin{array}{l}\text { MDA formation (nM of } \\
\text { MDA/gm) }\end{array}$ & $\begin{array}{l}\text { GSH (mg GSH/gm wet } \\
\text { tissue) }\end{array}$ & CAT $\left(\mu \mathrm{M}\right.$ of $\left.\mathrm{H}_{2} \mathrm{O}_{2} / \mathrm{gm}\right)$ & SOD (U/mg of tissue) \\
\hline Normal control & $3.2 \pm 0.4$ & $1.6 \pm 0.4$ & $13.2 \pm 2.2$ & $20.2 \pm 3.2$ \\
\hline Diabetic control & $8.6 \pm 0.8^{\#}$ & $0.5 \pm 0.2^{\#}$ & $6.5 \pm 0.7^{\#}$ & $9.1 \pm 1.3^{\#}$ \\
\hline CaRE (100) & $6.3 \pm 0.2$ & $1.2 \pm 0.2^{*}$ & $9.5 \pm 1.1^{*}$ & $18.6 \pm 1.9^{*}$ \\
\hline CaRE (200) & $4.3 \pm 1.0^{*}$ & $1.4 \pm 0.3^{* *}$ & $11.4 \pm 2.2 * *$ & $19.4 \pm 5.3 * *$ \\
\hline Glipizide (5) & $7.2 \pm 0.6$ & $0.6 \pm 0.2$ & $7.8 \pm 2.6$ & $13.5 \pm 2.4$ \\
\hline
\end{tabular}

- Table 4 Effects of CaRE on serum nitric oxide (NO), cytokines and serum biomarkers in STZ-diabetic rats.

\begin{tabular}{|c|c|c|c|c|c|}
\hline \multicolumn{6}{|c|}{ Effects of CaRE on serum nitric oxide (NO) and cytokines in STZ-diabetic rats } \\
\hline $\begin{array}{l}\text { Group and Treatment } \\
\text { (mg/kg, p.o.) }\end{array}$ & $\begin{array}{l}\text { NO }(\mathrm{mcg} / \mathrm{mg} \\
\text { protein) } \\
(\text { Mean } \pm S E M, n=6)\end{array}$ & $\begin{array}{l}\text { Serum Cytokines (pg/ } \\
\mathrm{mL} \text { ) (Mean } \pm \text { SEM, } \\
\mathrm{n}=6 \text { ) }\end{array}$ & & & \\
\hline & & TNF- $\alpha$ & IL-4 & & \\
\hline Normal control & $39.00 \pm 4.00$ & $154.90 \pm 65.41$ & $182.00 \pm 30.79$ & & \\
\hline Diabetic control & $89.00 \pm 9.00^{\# \#}$ & $387.60 \pm 50.24^{\# \#}$ & $472.60 \pm 60.16^{\# \#}$ & & \\
\hline CaRE (100) & $70.00 \pm 8.00$ & $291.30 \pm 31.97$ & $389.40 \pm 44.74$ & & \\
\hline CaRE (200) & $56.00 \pm 8.00^{*}$ & $182.00 \pm 30.39^{* *}$ & $302.00 \pm 31.16^{*}$ & & \\
\hline Glipizide (5) & $49.00 \pm 6.00^{* *}$ & $193.80 \pm 32.03^{* *}$ & $231.30 \pm 20.27^{* *}$ & & \\
\hline \multicolumn{6}{|c|}{ Effect of CaRE on serum biomarkers in STZ-diabetic rats } \\
\hline \multirow[t]{2}{*}{ Serum Biomarkers } & $\begin{array}{l}\text { Group and Treatment } \\
(\mathrm{mg} / \mathrm{kg}, \mathrm{p.o}) \\
(\text { Mean } \pm \text { SEM, } \mathrm{n}=6)\end{array}$ & & & & \\
\hline & Normal & Diabetic control & CaRE (100) & CaRE (200) & Glipizide (5) \\
\hline AST (U/L) & $22.2 \pm 3.5$ & $154.3 \pm 16.5^{\# \#}$ & $82.6 \pm 6.8^{* *}$ & $45.6 \pm 4.5^{* *}$ & $111.3 \pm 12.3^{*}$ \\
\hline $\operatorname{ALT}(\mathrm{U} / \mathrm{L})$ & $12.3 \pm 2.1$ & $80.4 \pm 12.3^{\# \#}$ & $37.2 \pm 1.5^{* *}$ & $22.6 \pm 5.2^{* *}$ & $52.3 \pm 6.5$ \\
\hline $\operatorname{ALP}(\mathrm{U} / \mathrm{L})$ & $10.3 \pm 1.6$ & $57.6 \pm 9.3^{\# \#}$ & $26.3 \pm 6.5^{* *}$ & $21.1 \pm 2.3^{* *}$ & $33.1 \pm 4.7^{*}$ \\
\hline Serum creatinine (mg/dL) & $0.8123 \pm 0.0100$ & $1.5570 \pm 0.0600^{\# \#}$ & $0.8205 \pm 0.0100^{*}$ & $0.9027 \pm 0.0200^{*}$ & $0.9862 \pm 0.0100^{*}$ \\
\hline $\begin{array}{l}\text { Blood urea nitrogen (mg/ } \\
\mathrm{dL} \text { ) }\end{array}$ & $20.60 \pm 1.07$ & $41.60 \pm 1.72^{\# \#}$ & $22.20 \pm 1.24^{* *}$ & $23.80 \pm 1.06^{* *}$ & $30.20 \pm 1.41^{*}$ \\
\hline Uric Acid (mg/dL) & $1.97 \pm 0.05$ & $2.94 \pm 0.08^{\# \#}$ & $2.11 \pm 0.02^{*}$ & $2.12 \pm 0.04^{*}$ & $2.43 \pm 0.07^{*}$ \\
\hline Total protein $(\mathrm{g} / \mathrm{dL})$ & $7.58 \pm 0.23$ & $3.97 \pm 0.17^{\# \#}$ & $7.01 \pm 0.33^{* *}$ & $7.26 \pm 0.16^{* *}$ & $4.95 \pm 0.08^{*}$ \\
\hline Albumin $(\mathrm{g} / \mathrm{dL})$ & $5.44 \pm 0.50$ & $1.93 \pm 0.10^{\# \#}$ & $4.15 \pm 0.36^{* *}$ & $4.47 \pm 0.26^{* *}$ & $2.44 \pm 0.06$ \\
\hline
\end{tabular}

ment of STZ diabetic rats with CaRE (100 and $200 \mathrm{mg} / \mathrm{kg} /$ day) and glipizide $(5 \mathrm{mg} / \mathrm{kg} /$ day) for 30 days led to a sustained reduction in blood glucose and maximum reduction was seen on the 30 th day, along with increased formation of and concomitant increase in glu- cose uptake by skeletal muscles, liver glycogen (glycogenesis), and gluconeogenesis. The hypoglycemic activity $200 \mathrm{mg} / \mathrm{kg}$ CaRE was observed to be comparable to that of $5 \mathrm{mg} / \mathrm{kg}$ glipizide. 

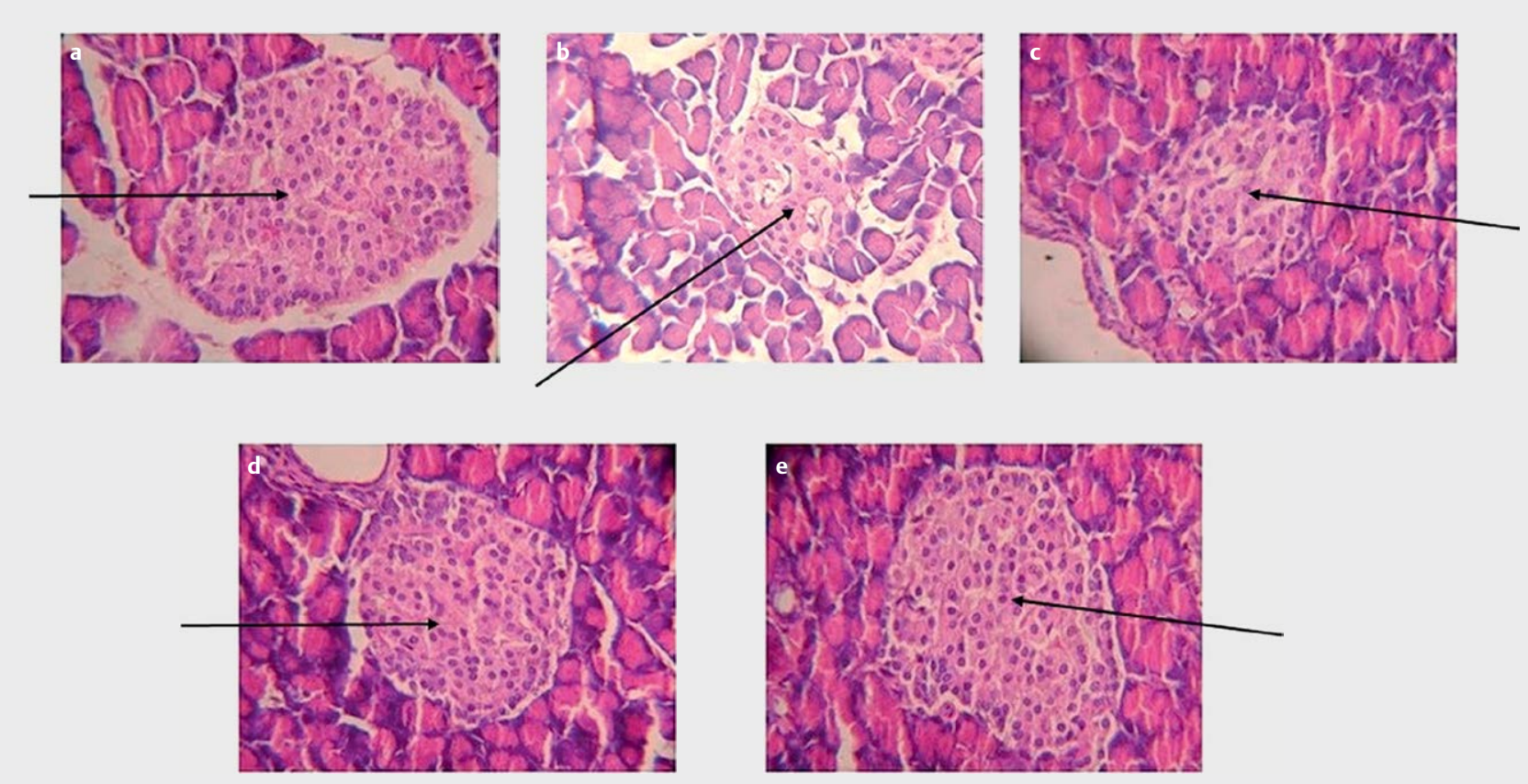

Fig. $4: 4 a$ - Effect of vehicle on histopathological changes in pancreas of normal rats; $4 \mathrm{~b}$ - Effect of vehicle on histopathological changes in pancreas of diabetic rats; $4 \mathrm{c}-$ Effect of CaRE $(100 \mathrm{mg} / \mathrm{kg})$ on histopathological changes in pancreas of diabetic rats; $4 \mathrm{~d}-\mathrm{Effect}$ of CaRE (200 mg/kg) on histopathological changes in pancreas of diabetic rats; $4 \mathrm{e}-$ Effect of Glipizide $(5 \mathrm{mg} / \mathrm{kg})$ on histopathological changes in pancreas of diabetic rats.

One of the possible mechanisms linking hyperglycemia and vascular complications is the increase in non-enzymatic glycosylation. It has been shown in previous studies that during type 2 diabetes mellitus, excess blood glucose and hemoglobin react in a two-step process to form glycosylated hemoglobin (GHbA1c) [16]. This glycosylated HbA1c has been recommended as a standard of care to monitor type 2 diabetes mellitus. Therefore, we assessed the effect of CaRE treatment on the levels of glycosylated HbA1c. Treatment with CaRE and glipizide reduced the elevation of glycosylated hemoglobin significantly. The inhibitory effect of CaRE on GHbA1c in STZ diabetic rats was comparable to that induced by glipizide.

Oxidative stress plays a major role in type 2 diabetes mellitus pathogenesis. It is often responsible for the tissue damage associated with type 2 diabetes mellitus [17]. In diabetic patients, nonenzymatic protein glycation, oxidation of glucose, and increased lipid peroxidation leads to the generation of free radicals. This leads to the enzymatic degradation of cells and elevation in insulin resistance. Recent studies have shown that even the apolipoprotein component of LDL forms insoluble aggregates in the presence of hydroxyl radicals, leading to oxidative damage [18]. The main source of oxidative stress is the mitochondria. Modulation of insulin signaling by reactive oxygen or nitrogen species occurs via two ways. In response to insulin, these reactive oxygen/nitrogen species are produced for their physiological function and these reactive oxygen/nitrogen species negatively impact insulin signaling, which leads to insulin resistance [18]. The formation of free radicals may finally lead to the formation of MDA, a reactive aldehyde responsible for the formation of covalent protein adducts called advanced epoxidation end products.
Various studies have shown increased levels of MDA in diabetic patients, which has been associated with a poor prognosis of type 2 diabetes mellitus. A study was conducted with 120 diabetic patients, and it was found that MDA levels were high in type 2 diabetes mellitus patients and prediabetic patients compared to control group, suggesting that MDA levels are augmented during the progression of type 2 diabetes mellitus [19]. The MDA level has also been associated with insulin resistance. One study aimed to evaluate MDA levels in 96 prediabetic and 101 diabetic patients and establish its correlation to the Homeostatic Model Assessment of Insulin Resistance for the same subjects. It showed a statistically significant correlation between the level of MDA and insulin resistance in obese prediabetic patients [20]. Taking these results into consideration, we assessed if CaRE has potential to reduce the level of MDA. Superoxide dismutase catalyzes superoxide anions, which induce oxidative damage to cell membranes. GSH is a non-protein thiol found in all mammalian tissues. It is an efficient antioxidant that serves as an oxidative stress biomarker [21]. Depletion of SOD and GSH levels has been observed in type 2 diabetes mellitus patients [22].

The levels of antioxidant enzymes and lipid peroxidation were assessed in 90 type 2 diabetes mellitus patients and it was found that MDA levels were high in type 2 diabetes mellitus patients and levels of SOD and GSH were reduced [23]. Decreased levels of GSH might be one of the factors responsible for oxidative DNA damage in type 2 diabetes mellitus. The depletion of GSH and SOD may be attributed to diabetes-induced oxidative stress and free radical overproduction. CAT is another antioxidant enzyme found in peroxisomes and catalyzes $\mathrm{H}_{2} \mathrm{O}_{2}$ to $\mathrm{H}_{2} \mathrm{O}$ and $\mathrm{O}_{2}$. These antioxidant enzymes work together to protect cells from free radicals induced by 
oxidative stress $[17,24]$. In the present study, we assessed if CaRE treatment has any effect on the levels of MDA, SOD, and GSH. CaRE treatment (30 days) prevented elevated MDA formation in the liver and pancreas of STZ diabetic rats, and we hypothesized that these effects might have helped restore the impaired endogenous antioxidant system and reinstate balanced antioxidant homeostasis in diabetic rats. Such antioxidant effects have likely contributed to its antidiabetic activity [25].

Various studies conducted on human and animal models have supported the fact that inflammation has a role in the initiation and progression of type 2 diabetes mellitus [26]. Cumulatively, evidence has suggested that the activation of inflammatory signaling pathways in the target cells of insulin action could be a contributing factor towards obesity, resistance to insulin, and related metabolic disorders, viz. type 2 diabetes mellitus [27].

Various studies have proven that the insulin resistance is associated with abnormal proinflammatory cytokine secretion and reduced anti-inflammatory cytokine generation [28]. Type 2 diabetes mellitus is often characterized by impairment of insulin function, which leads to metabolic syndrome [29]. TNF- $\alpha$ has been found to play a crucial role in insulin resistance. It also reduces glucose transporter type 4 expression [30]. Furthermore, activation of TNF- $\alpha$ induces the phosphorylation of the insulin receptor substrate-1, which works as an inhibitor of insulin receptors and downregulates phosphatidylinositol-3 kinase activation [31, 32]. TNF- $\alpha$ levels have been observed to be elevated in type 2 diabetes mellitus patients of all age, disease duration, and ethnicity [33].

IL-4 contributes towards insulin resistance, which leads to increased glycogenolysis and decreased gluconeogenesis [34]. We observed a decrease in levels of proinflammatory mediators TNF$\alpha$ and IL- 4 after CaRE treatment, indicating that CaRE inhibits the secretion of these cytokines, thereby indicating improvement in insulin sensitivity. Our findings corroborate those of a previous study wherein improvement in insulin sensitivity was observed during long-term treatment with anti-TNF- $\alpha$ antibody infliximab in subjects who were insulin resistant [35].

Lipid abnormalities in diabetic patients, often termed as "diabetic dyslipidemia”, are characterized by high TC (Total cholesterol), LDL (low-density lipoprotein), and TG (triglycerides) levels, and low HDL (High-density lipoprotein) levels [36]. These abnormalities are common in prediabetic and type 2 diabetes mellitus patients. A recently published study suggested an association between a risk of type 2 diabetes mellitus and these lipid parameters [37]. Previously, hypertriglyceridemia and hypercholesterolemia have been reported in alloxan diabetic rats [38]. Various factors contribute towards the alteration in lipid metabolism in patients with type 2 diabetes mellitus, such as insulin deficiency or resistance, adipocytokines, and hyperglycemia. It has previously been shown that deficiency or insulin resistance results in the activation of intracellular hormone-sensitive lipase, leading to the increased release of NEFAs from the TGAs. This high circulating level of NEFA could increase the production of TGAs by the liver [36].

Diabetic dyslipidemia is a crucial risk factor of diabetes-associated cardiovascular disorders. Therefore, the treatment of dyslipidemia is an important strategy for the management of type 2 diabetes mellitus. We found that CaRE showed hypolipidemic activity in rats, further suggesting that CaRE could not only lower glucose levels but could also manage other complications associated with type 2 diabetes mellitus. The exact underlying mechanisms(s) for CaRE's hypolipidemic activity observed in the present experiments is not known. However, it is presumed that CaRE may directly downregulate $\mathrm{NADH}$ and $\mathrm{NADPH}$. The other mechanisms responsible for the hypolipidemic effect of CaRE include (1) inhibition of lipase or/ and an inhibitory effect on lipolytic hormones on the fat depots and (2) cholesterol biosynthesis or absorption of lipids from the gastrointestinal tract or uptake process.

The hypolipidemic activity displayed by CaRE is beneficial and may be useful to reduce cardiovascular complications in diabetic conditions and may help to ameliorate the risk of acute myocardial infarction as claimed by the NCEP guidelines (2002) [39]. Increased hepatic serum markers, like transaminases, including ALP, have been documented in experimental models of type 2 diabetes mellitus [40]. The increased transaminases indicate impaired hepatic function largely due to cellular damage to hepatocytes. Furthermore, the increased transaminases may serve as a substrate to amino acids, thereby enhancing gluconeogenesis as well as ketogenesis. Such observations have also been clinically documented in diabetic patients [41]. In the present study, CaRE (100 and $200 \mathrm{mg} / \mathrm{kg}$ ) and glipizide treatment in STZ diabetic rats inhibited the increased serum transaminases, which may be attributed to their hypoglycemic activity and/or modulation of carbohydrate, lipid, and protein metabolism. Alternatively, the decreased serum transaminases may be attributed to decreased oxidative stress and, consequently, reduced cytotoxicity to hepatocytes. Oxidative stress due to reactive lipid peroxidation recruits inflammatory cells and can be a potential triggering factor for the increased serum transaminases and enhanced formation of proinflammatory cytokines (IL-4 and TNF- $\alpha$ ) in type 2 diabetes mellitus [42].

STZ treatment produced atrophy of $\beta$-islets of Langerhans associated with severe necrosis represented by pyknotic nuclei and acidophilic cytoplasm in the necrotic cells along with vascular degenerative alteration, resulting in the reduction of size and number of $\beta$-islets significantly. Only a sporadic presence was observed in few rats. The treatment of STZ diabetic rats with CaRE prevented the degree of necrosis dose-dependently. The improvement of necrosis of $\beta$-islets after treatment with $200 \mathrm{mg} / \mathrm{kg}$ CaRE was comparable to that induced by treatment with $5 \mathrm{mg} / \mathrm{kg}$ glipizide. Furthermore, the size and number of $\beta$-islets also improved after treatment with $200 \mathrm{mg} / \mathrm{kg}$ CaRE and $5 \mathrm{mg} / \mathrm{kg}$ glipizide. The reduction in necrosis and improvement in size and numbers of $\beta$-islet of Langerhans can be attributed to the amelioration of oxidative stress, which also leads to stabilization of their membranes.

The HPTLC analysis of CaRE revealed the presence of $\beta$-sitosterol as an active constituent. HPTLC analysis also showed the presence of alkaloid and saponin classes of compounds. It has been reported that $\beta$-sitosterol exerts an inhibitory effect on glycated hemoglobin, thiobarbituric acid-reactive substances, blood glucose, and nitric oxide, with upregulation in serum insulin levels and pancreatic antioxidant levels [43]. In agreement with these findings, Bumrela et al. have also confirmed the antioxidant potential of $\beta$ sitosterol both in vivo and in vitro [44]. HPTLC analysis also demonstrated the presence of saponins, which could be oleanolic acid, ursolic acid, and lupeol. Both oleanolic acid and ursolic acid showed significant protection against chemically induced liver injury in an- 
imal models. Oleanolic acid and ursolic acid have also been long recognized to exert antihyperlipidemic and anti-inflammatory effects [45]. Various in vitro and animal studies demonstrated that lupeol possesses a potential cholesterol-lowering activity [46]. Further, caulerpin, a bisindole alkaloid, has also been isolated by De Souza et al. Further, caulerpin, a bisindole alkaloid, has also been isolated by Lucenaet al. from CaRE and found to be a potent antiinflammatory agent in various models of inflammation [47].

The antidiabetic and antioxidant activities exhibited by the phytoconstituents isolated (identified by HPTLC analysis) from the ethanolic extract of $\mathrm{CaRE}$ are in agreement with the various biological activities reported in the literature. The present experimental findings of CaRE demonstrated significant antidiabetic activity in STZ diabetic rats. The various biochemical paradigms observed in STZ diabetes included decreased glucose and lipid metabolism, reduction in levels of proinflammatory mediators, and oxidative stress alleviation. Histopathological studies suggested its antidiabetic activity is derived from the antioxidant activity. Downregulation of proinflammatory mediators improves the histoarchitecture of $\beta$ islets. Such effects may be attributed to the presence of saponins, $\beta$-sitosterol, and other phytochemicals. Further, saponins and $\beta$ sitosterol found in the extract may be responsible for such beneficial therapeutic effects. Hypolipidemic activity may be beneficial for patients with type 2 diabetes mellitus. CaRE seems to be safe and doesn't affect vital organs adversely. CaRE needs to be further assessed through human clinical trials to assess its therapeutic efficacy in type 2 diabetes mellitus.

\section{Materials and Methods}

\section{Plant material}

CaR seaweed was collected from the coastal area of Okha port in the Gujarat state of India. The collected seaweed sample was authenticated by the Department of Botany of a seaweed-based organization, Carrag Seaveg Pvt. Ltd., Bhavnagar, Gujarat, India. A voucher herbarium specimen, number CSPL/GA/CR07-09, has been preserved at CarragSeaveg.

\section{Drugs and chemicals}

Glipizide powder (purity: 99.9\%) was obtained from USV Pharma. STZ was procured from Sigma-Aldrich. Commercial kits used for biochemical analysis were: glucose reagent kit GOD/POD end point (Biolab), serum glutamate oxaloacetate transaminase (SGOT/AST) determination kit (Accurex Biomedical Pvt. Ltd.), serum glutamate pyruvate transaminase (SGPT/ALT) determination kit (Accurex Biomedical Pvt. Ltd.), alkaline phosphatase determination kit (Accurex Biomedical Pvt. Ltd.), lipid profile kit (Nirmal Labs), Keto-Test GK test strips for urine glucose determination (Diascreen), renal function parameters kit (Nirmal Labs), and reagent strips for urinalysis (Hypoguard). The control, test item, and reference drug were dissolved in $1 \%$ CMC.

\section{Preparation of extract}

Samples of dried seaweed were prepared by cutting or crushing the seaweed into small pieces and then grinding into a coarse powder. Coarse powders $(50 \mathrm{~g}$ ) were extracted with $500 \mathrm{~mL}$ of absolute ethanol (95\%) using a Soxhlet extractor at $500^{\circ} \mathrm{C}$. Occasional shaking was carried out for a period of $72 \mathrm{~h}$. This crude extract was filtered off and subsequently evaporated to dryness at $45^{\circ} \mathrm{C}$. The concentrated dry mass was used for further investigations. The extract obtained was in ethanol.

\section{High-performance thin-layer chromatography analysis of Caulerpa racemosa ethanolic extract}

CaRE $(10 \mathrm{mg}$ ) was dissolved in $10 \mathrm{~mL}$ of chloroform (final concentration: $1000 \mathrm{ng} / \mu \mathrm{L}$ ) and analyzed using a CAMAG LINOMATE V automatic sample applicator on a $10 \times 10 \mathrm{~cm} \mathrm{HPTLC}$ plate coated with $250 \mu \mathrm{m}$ layers of Silica gel G 60 F254 (Merck) and solvent system. Petether:acetone [(8:2) (v/v)] was used as the mobile phase. A Scanner-3 (CAMAG) was used to perform densitometer scans at $366 \mathrm{~nm}$. The plates were derivatized in Liebermann-Burchard reagent.

\section{Animals}

Adult female mice (Mus musculu Swiss; $18-20 \mathrm{~g}$ ) and male mice (Rattus norvegicus Wistar; 200-250 g) (age:10-12 weeks) were used for the study. They were housed under standard conditions (room temperature: $24 \pm 3{ }^{\circ} \mathrm{C}$, relative humidity: $45-55 \%, 12: 12$ dark/light cycle). They were fed ad libitum and given filtered tap water. Standard pellet diet was provided. The experimental protocol was reviewed and approved (CPCSEA/IAEC/SPTM/P-14/2014) by the Institutional Animal Ethics Committee for Purpose of Control and Supervision of Experimental Animals.

\section{Acute toxicity studies}

OECD guideline 423 (OECD 2001) in Swiss albino mice was followed for the acute toxicity study. The mice were orally administered CaRE $(300-2000 \mathrm{mg} / \mathrm{kg})$ solutions in $1 \%$ CMC. The mice were then kept under observation for $72 \mathrm{~h}$.

\section{Experimental induction of type 2 diabetes mellitus}

STZ $(55 \mathrm{mg} / \mathrm{kg})$ solution in $0.1 \mathrm{M}$ cold citrate buffer $(\mathrm{pH} 4.5)$ was administered intraperitoneally. Blank citrate buffer was used for the control mice. Initially, Wistar rats were screened for pre-dose glucose levels and then STZ was administered for inducing type 2 diabetes mellitus. After $72 \mathrm{~h}$, blood was withdrawn from all animals and blood glucose levels were analyzed again. Mice with fasting blood glucose levels above $300 \mathrm{mg} / \mathrm{dL}$ and exhibiting polydipsia and polyphagia were selected for the 30-day anti-diabetic study.

\section{Antidiabetic activity evaluation in streptozotocin- induced diabetic rats}

Acute dose-response

Overnight fasted STZ diabetic rats were divided into groups of six rats each as follows: group I comprised normal control rats orally administered with $1 \% \mathrm{CMC}$ solution $(10 \mathrm{~mL} / \mathrm{kg})$,

group II comprised diabetic control rats [diabetic rats orally administered $1 \% \mathrm{CMC}$ solution $(10 \mathrm{~mL} / \mathrm{kg})$ ], group III comprised diabetic rats orally administered CaRE $(100 \mathrm{mg} / \mathrm{kg})$ in $1 \%$ CMC, group IV comprised diabetic rats orally administered CaRE $(200 \mathrm{mg} / \mathrm{kg})$ in $1 \% \mathrm{CMC}$, and group $\mathrm{V}$ comprised diabetic rats orally administered glipizide $(5 \mathrm{mg} / \mathrm{kg})$ in $1 \%$ CMC. Fasting blood glucose levels 
were 3 estimated from retro-orbital sinus prior to and at 1,3 , and $6 \mathrm{~h}$ after treatment [48].

\section{Subacute (30 day) response at double dose}

The same animals of the single-dose short-term study were continued at two different doses of CaRE (100 and $200 \mathrm{mg} / \mathrm{kg}$ ) or glipizide $(5 \mathrm{mg} / \mathrm{kg}$ ) orally daily for 30 days. Blood glucose levels were assayed on the 10th, 20th, and 30th days after drug/CaRE treatment. Animals were sacrificed by euthanasia on the 31st day and the liver, pancreas, and diaphragm were extracted, washed with cold saline, and preserved under $-20^{\circ} \mathrm{C}$ until used for various biochemical investigations.

\section{Carbohydrate metabolism}

Determination of glycosylated hemoglobin (HbA1c)

The glucose level in the blood plasma was evaluated using glucose estimation kits. Glycosylated hemoglobin (HbA1c) was assessed using a previously proposed method Parker et al. [49].

\section{Estimation of liver glycogen}

The liver glycogen level was estimated using a previously proposed method [50]. The supernatant was mixed with $95 \%$ ethanol in a 1:5 ratio and incubated overnight for glycogen precipitation. Then, the glycogen precipitate was dissolved in distilled water $(2 \mathrm{~mL})$. The standard and blank solutions were prepared using glucose $(0.5 \mathrm{mg} /$ $\mathrm{mL}$ ) and distilled water, respectively. Next, anthrone reagent $(5 \mathrm{~mL})$ was added to all tubes, which were then incubated in a boiling water bath for $15 \mathrm{~min}$. Then, absorbance was measured at $620 \mathrm{~nm}$. Results are expressed as $\mathrm{mg}$ glycogen/g tissue [51].

\section{Glucose uptake and glucose transport}

The mice were sacrificed under ether anesthesia and their livers and diaphragm were extracted. The excised tissues were immediately placed in ice-cold perfusion solution [containing $\mathrm{KCl}(0.04 \%), \mathrm{NaCl}$ (0.687\%), $\mathrm{MgSO}_{4}(0.014 \%), \mathrm{NaHPO}_{4}(0.014 \%), \mathrm{CaCl}_{2}(0.028 \%)$, $\left.\mathrm{NaHCO}_{3}(0.21 \%)\right]$. In another batch of perfusate, glucose at a concentration of $400 \mathrm{mg} \%$ was taken. Next, the tissue slices were incubated at $37^{\circ} \mathrm{C}$ for $1.5 \mathrm{~h}$ with appropriate aeration. Thereafter, the slices were washed with water and oven-dried at $800^{\circ} \mathrm{C}$ for $4-5 \mathrm{~h}$. The glucose uptake was measured as $\mathrm{mg}$ glucose/100 mg dry weight of the diaphragm, while glucose levels in perfusate were measured as mg glucose/g of dry weight of the liver [52].

\section{Lipid profile}

Serum levels of TC, TGA, HDL, LDL, and VLDL were assayed using respective analytical kits (Nirmal Labs).

\section{Antioxidant, inflammatory, and serum biomarkers}

The liver and pancreas were extracted as described previously, washed with ice-cold saline, and weighed. Tissue homogenates $(10 \% \mathrm{w} / \mathrm{v})$ were prepared in cold $0.1 \mathrm{M}$ phosphate buffer solution $(\mathrm{pH} 7.4)$ and used to determine MDA formation [53]. Cell debris was removed by centrifugation $\left(10000 \times \mathrm{g}\right.$ at $4{ }^{\circ} \mathrm{C}$ for $\left.20 \mathrm{~min}\right)$ and the supernatant was assayed to determine nitrite levels [54] and enzyme antioxidants, viz. superoxide dismutase [55], CAT [56], and reduced GSH [57]. The inflammatory biomarkers, including cy- tokines, TNF- $\alpha$ and IL-4, serum markers (AST, ALT), and ALP, were assayed on the 31 st day using commercial kits.

\section{Histoarchitecture of the pancreas}

Pancreatic tissue was extracted and preserved in $10 \%$ formalin. After fixation, tissues were embedded in paraffin. Then, the $3-4 \mu \mathrm{m}$ thick sections were cut and stained using eosin and hematoxylin. The stained specimens were then examined under a light microscope $(40 \times)$.

\section{Statistical analysis}

The results are expressed as the mean \pm SEM. Statistical analysis was performed through ANOVA followed by Dunnett's test. CaREand glipizide-treated groups were compared with the corresponding normal or diabetic control groups. Statistical significance was indicated by $\mathrm{p}<0.05$. SPSS and Graph Pad Prism Version 08 were used for statistical analysis.

\section{Conflict of Interest}

The authors declare that they have no conflict of interest.

\section{References}

[1] Rotter Ana, Barbier Michéle, Bertoni Francesco, Bones Atle M., Cancela M. Leonor, Carlsson Jens, Carvalho Maria F., Cegłowska Marta, Chirivella-Martorell Jerónimo, Conk Dalay Meltem, Cueto Mercedes, Dailianis Thanos, Deniz Irem, Díaz-Marrero Ana R., Drakulovic Dragana, Dubnika Arita, Edwards Christine, Einarsson Hjörleifur, Erdoğan Ayşegül, Eroldoğan Orhan Tufan, Ezra David, Fazi Stefano, FitzGerald Richard J., Gargan Laura M., Gaudêncio Susana P., Gligora Udovič Marija, Ivošević DeNardis Nadica, Jónsdóttir Rósa, Kataržytė Marija, Klun Katja, Kotta Jonne, Ktari Leila, Ljubešić Zrinka, Lukić Bilela Lada, Mandalakis Manolis, Massa-Gallucci Alexia, Matijošytẻ Inga, MazurMarzec Hanna, Mehiri Mohamed, Nielsen Søren Laurentius, Novoveská Lucie, Overlingė Donata, Perale Giuseppe, Ramasamy Praveen, Rebours Céline, Reinsch Thorsten, Reyes Fernando, Rinkevich Baruch, Robbens Johan, Röttinger Eric, Rudovica Vita, Sabotič Jerica, Safarik Ivo, Talve Siret, Tasdemir Deniz, Theodotou Schneider Xenia, Thomas Olivier P., Toruńska-Sitarz Anna, Varese Giovanna Cristina, Vasquez Marlen I. The essentials of marine biotechnology. Front Mar Sci 2021; 16: 158

[2] Jiao G, Yu G, Zhang J, Ewart HS. Chemical structures and bioactivities of sulfated polysaccharides from marine algae. Mar Drugs 2011; 9: 196-233

[3] Ota A, Ulrih NP. An Overview of Herbal Products and Secondary Metabolites Used for Management of Type Two Diabetes. Front Pharmacol 2017; 8: 436: 1-16

[4] Rizvi SI, Mishra N. Traditional Indian medicines used for the management of diabetes mellitus. J Diabetes Res 2013; 2013: 712092

[5] Gunathilaka T, Keertihirathna LR, Peiris D. Advanced pharmacological uses of marine algae as an anti-diabetic therapy. In: El-Shemy $\mathrm{H}$, editor. Pharmacognosy-medicinal plants. IntechOpen; 2021

[6] Nowotny K, Jung T, Höhn A, Weber D, Grune T. Advanced glycation end products and oxidative stress in type 2 diabetes mellitus. Biomolecules 2015; 5: 194-222 
[7] McKeegan K, Mason SA, Trewin AJ, Keske MA, Wadley GD, Della Gatta PA, Della Gatta PA, Nikolaidis MG, Parker L. Reactive oxygen species in exercise and insulin resistance: Working towards personalized antioxidant treatment. Redox Biol 2021; 44: 102005

[8] Kumar M, Gupta V, Kumari P, Reddy CRK, Jha B. Assessment of nutrient composition and antioxidant potential of Caulerpaceae seaweeds. J Food Compos Anal 2011; 24: 270-278

[9] Yap WF, Tay V, Tan SH, Yow YY, Chew J. Decoding antioxidant and antibacterial potentials of Malaysian green seaweeds: Caulerpa racemosa and Caulerpa lentillifera. Antibiotics 2019; 8: 152: 1-18

[10] Nagaraj SR, Osborne JW. Bioactive compounds from Caulerpa racemosa as a potent larvicidal and antibacterial agent. Front Biol 2014; 9: 300-305

[11] Ribeiro NA, Abreu TM, Chaves HV, Bezerra MM, Monteiro HS, Jorge R], Benevides NM. Sulfated polysaccharides isolated from the green seaweed Caulerpa racemosa plays antinociceptive and antiinflammatory activities in a way dependent on $\mathrm{HO}-1$ pathway activation. Inflamm Res 2014; 63: 569-580

[12] Cao M, Li Y, Famurewa AC, Olatunji OJ. Antidiabetic and Nephroprotective Effects of Polysaccharide Extract from the Seaweed Caulerpa racemosa in High Fructose-Streptozotocin Induced Diabetic Nephropathy. Diabetes Metab Syndr ObesTargets Ther 2021; 14: 2121

[13] El-Borady OM, Othman MS, Atallah HH, Moneim AEA. Hypoglycemic potential of selenium nanoparticles capped with polyvinyl-pyrrolidone in streptozotocin-induced experimental diabetes in rats. Heliyon 2020; 6: e04045

[14] Wei L, Lu Y, He S, jin X, Zeng L, Zhang S, Chen Y, Tian B, Mai G, Yang G, Zhang J, Wang L, Li H, Markmann JF, Cheng J, Deng S. Induction of diabetes with signs of autoimmunity in primates by the injection of multiple-low-dose streptozotocin. Biochem Biophys Res Commun 2011; 412: 373-378

[15] Naik SR, Shaikh N, Patil RR, Somani RS, Mali AS. Protective activity profile of herbomineral medicine in early diabetic nephropathy rats: restoration of kidney antioxidants, hemodynamics and suppression of proinflammatory mediators. Biomed Aging Pathol 2014; 4: 33-41

[16] Sherwani SI, Khan HA, Ekhzaimy A, Masood A, Sakharkar MK. Significance of HbA1c Test in Diagnosis and Prognosis of Diabetic Patients. Biomark Insights 2016; 11: 95-104

[17] Al-Numair KS, Chandramohan G, Veeramani C, Alsaif MA. Ameliorative effect of kaempferol, a flavonoid, on oxidative stress in streptozotocininduced diabetic rats. Redox Rep 2015; 20: 198-209

[18] Asmat U, Abad K, Ismail K. Diabetes mellitus and oxidative stress - A concise review. Saudi Pharm J 2016; 24: 547-553

[19] Sharma R, Satyanarayana P, Anand P, Kumari GA. Adiponectin Level Association with MDA in the Patients with Type 2 Diabetes Mellitus. Biomed Pharmacol ] 2020; 13: 943-955

[20] Kar K, Bhattacharyya A, Paria B. Elevated MDA Level Correlates with Insulin Resistance in Prediabetes. J Clin Diagn Res 2018; 12: 22-24

[21] Lu SC. Glutathione synthesis. Biochim Biophys Acta Gen Subj 2013; 1830: 3143-3153

[22] Rahigude A, Bhutada P, Kaulaskar S, Aswar M, Otari K. Participation of antioxidant and cholinergic system in protective effect of naringenin against type- 2 diabetes-induced memory dysfunction in rats. Neuroscience 2012; 226: 62-72

[23] Kumawat M, Sharma TK, Singh I, Singh N, Ghalaut VS, Vardey SK. Antioxidant enzymes and lipid peroxidation in type 2 diabetes mellitus patients with and without nephropathy. N Am J Med Sci 2013; 5: 213

[24] Tiwari BK, Pandey KB, Abidi AB, Rizvi SI. Markers of Oxidative Stress during Diabetes Mellitus. J Biomark 2013; 2013: 378790

[25] Wang Y, Xiang L, Wang C, Tang C, He X. Antidiabetic and antioxidant effects and phytochemicals of mulberry fruit (Morus alba I.) polyphenol enhanced extract. PLoS One 2013; 8: e71144
[26] Marques-Vidal P, Schmid R, Bochud M, Bastardot F, von Känel R, Paccaud F, Glaus J, Preisig M, Waeber G, Vollenweider P. Adipocytokines, hepatic and inflammatory biomarkers and incidence of type 2 diabetes. The CoLaus Study. PLoS One 2012; 7: e51768

[27] Kengne AP, Batty GD, Hamer M, Stamatakis E, Czernichow S. Association of C-reactive protein with cardiovascular disease mortality according to diabetes status: pooled analyses of 25,979 participants from four UK prospective cohort studies. Diabetes Care 2012; 35: 396-403

[28] Xiao J, Li ], Cai L, Chakrabarti S, Li X. Cytokines and diabetes research. ] Diabetes Res 2014; 2014: 920613. doi: 10.1155/2014/920613. Epub 2014 Jan 16. PMID: 24551859; PMCID: PMC3914520

[29] Ormazabal V, Nair S, Elfeky O, Aguayo C, Salomon C, Zuñiga FA. Association between insulin resistance and the development of cardiovascular disease. Cardiovasc Diabetol 2018; 17: 1-4

[30] Olmos G, Lladó ]. Tumor necrosis factor alpha: a link between neuroinflammation and excitotoxicity. Mediat Inflamm 2014; 2014: 12

[31] Akash MS, Rehman K, Liaqat A. Tumor necrosis factor-alpha: role in development of insulin resistance and pathogenesis of type 2 diabetes mellitus. J Cell Biochem 2018; 119: 105-110

[32] Rehman K, Akash MS. Mechanisms of inflammatory responses and development of insulin resistance: how are they interlinked? J Biomed Sci 2016; 23: 1-8

[33] Qiao YC, Chen YL, Pan YH, Tian F, Xu Y, Zhang XX, Zhao HL. The change of serum tumor necrosis factor alpha in patients with type 1 diabetes mellitus: A systematic review and meta-analysis. PLoS One 2017; 12: e0176157

[34] Al-Hakeim HK, Al-Kufi SN, Al-Dujaili AH, Maes M. Serum Interleukin Levels and Insulin Resistance in Major Depressive Disorder. CNS Neurol Disord Drug Targets 2018; 17: 618-625

[35] Donath MY. Targeting inflammation in the treatment of type 2 diabetes: time to start. Nat Rev Drug Discov 2014; 13: 465-476

[36] Jonathan D, Schofield JD, Liu Y, Rao-Balakrishna P, Malik RA, Soran H. Diabetes dyslipidemia. Diabetes Ther 2016; 7: 203-219

[37] Santos-Gallego CG, Rosenson RS. Role of HDL in those with diabetes. Curr Cardiol Rep 2014; 16: 1-4

[38] Erejuwa OO, Nwobodo NN, Akpan JL, Okorie UA, Ezeonu CT, Ezeokpo BC, Nwadike KI, Erhiano E, Abdul Wahab MS, Sulaiman SA. Nigerian Honey Ameliorates Hyperglycemia and Dyslipidemia in AlloxanInduced Diabetic Rats. Nutrients. 2016 Feb 24;8(3):95. doi: 10.3390/ nu8030095. PMID: 26927161; PMCID: PMC4808836.

[39] Opoku S, Gan Y, Yobo EA, Tenkorang-Twum D, Yue W, Wang Z, Lu Z. Awareness, treatment, control, and determinants of dyslipidemia among adults in China. Sci Rep 2021; 12(1): 10056

[40] Rao UM, Adinew B. Remnant B-cell-stimulative and anti-oxidant effects of Persea americana fruit extract studied in rats introduced into streptzotocin-induced hyperglycaemic state. Afr J Tradit Complement Altern Med 2011; 8: 210-217

[41] Mandal A, Bhattarai B, Kafle P, Khalid M, Jonnadula SK, Lamicchane J, Kanth R, Gayam V. Elevated Liver Enzymes in Patients with Type 2 Diabetes Mellitus and Non-alcoholic Fatty Liver Disease. Cureus 2018; 10: e3626

[42] Tangvarasittichai S. Oxidative stress, insulin resistance, dyslipidemia and type 2 diabetes mellitus. World J Diabetes 2015; 6: 456

[43] Gupta R, Sharma AK, Dobhal MP, Sharma MC, Gupta RS. Antidiabetic and antioxidant potential of $\beta$-sitosterol in streptozotocin-induced experimental hyperglycemia. J Diabetes 2011; 3: 29-37

[44] Bumrela S, Bumrela SB, Naik SR. Identification of $\beta$-carotene and $\beta$-sitosterol in methanolic extract of Dipteracanthus patulus (Jacq) nees and their role in antimicrobial and antioxidant activity. Int J Phytomedicine 2011; 3: 204-215 
[45] Siddique HR, Saleem M. Beneficial health effects of lupeol triterpene: a review of preclinical studies. Life Sci 2011; 88: 285-293

[46] Siddique HR, Saleem M. Beneficial health effects of lupeol triterpene: a review of preclinical studies. Life Sci 2011; 88: 285-293

[47] Lucena AMM, Souza CRM, Jales JT, Guedes PMM, de Miranda GEC, de Moura AMA, Araújo-Júnior JX, Nascimento GJ, Scortecci KC, Santos BVO, Souto JT The Bisindole Alkaloid Caulerpin, from Seaweeds of the Genus Caulerpa, Attenuated Colon Damage in Murine Colitis Model. Marine drugs 2018; 16: 318

[48] Nagja T, Kumar V, Sanjeev A. Anti-diabetic activity of a polyherbal formulation in Streptozotocin induced Type 2 Diabetic rats. J Nat Remedies 2017; 16: 148-152

[49] Parker KM, England JD, Da Costa J, Hess RL, Goldstein DE. Improved colorimetric assay for glycosylated hemoglobin. Clin Chem. 1981 May;27(5):669-672

[50] Carroll NV, Longley RW, Roe JH. The determination of glycogen in liver and muscle by use of anthrone reagent. J Biol Chem 1956; 220: 583-593

[51] Patel DK, Krishnamurthy S, Hemalatha S. Evaluation of glucose utilization capacity of bioactivity guided fractions of Hybanthus enneaspermus and Pedalium murex in isolated rat hemidiaphragm. J Acute Dis 2013; 2: 33-36
[52] Arumugam S, Natesan S. Hypoglycemic effects of Barleria Noctiflora fractions on high fat fed with low dose Streptozotocin induced type-2 diabetes in rats. Int ] Pharm Pharm Sci 2016; 8: 193-200

[53] Simeonova R, Vitcheva V, Kondeva-Burdina M, Popov G, Shkondrov A, Manov V, llina K. Alcesefoliside protects against oxidative brain injury in rats. Rev Bras Farmacogn 2019; 29: 221-227

[54] Green LC, Wagner DA, Glogowski ], Skipper PL, Wishnok JS, Tannenbaum SR. Analysis of nitrate, nitrite, and [15N] nitrate in biological fluids. Anal Biochem 1982; 126: 131-138

[55] Misra HP, Fridovich I. The role of superoxide anion in the autoxidation of epinephrine and a simple assay for superoxide dismutase. J Biol Chem 1972; 247: 3170-3175

[56] Aebi H. Catalase in vivo. In: Methods of enzymology. Volume 105:New York: Academic Press; 1984: 673-684

[57] Moron MS, Depierre JW, Mannervik B. Levels of glutathione, glutathione reductase and glutathione S-transferase activities in rat lung and liver. Biochim Biophys Acta Gen Subj 1979; 582: 67-78 